\section{The Biological Council}

AT its meeting on March 20, the Biological Council elected Prof. J. F. Danielli as its honorary treasurer and Dr. L. Broadbent as its honorary secretary. Two societies, the British Herpetological Society and the British Society for Immunology, were accepted for affiliation to the Council, bringing the number of affiliated societies up to twenty-five.

\section{The Queen's University of Belfast: Appointments}

THE following appointments in The Queen's University of Belfast are announced: Dr. J. R. Beloff, to a lectureship in psychology; W. E. Coey, to a lectureship in crop and animal husbandry; Dr. W. T. E. McCaughey, to a lectureship in applied pathology ; T. R. F. Nonweiler, to a senior lectureship in aeronautical engineering; Dr. E. M. Pantelouris, to a lectureship in zoology; Dr. D. C. J. Burgess, to 8 lectureship in pure mathematics.

\section{University of Leeds : Appointments}

The following appointments in the University of Leeds are announced : the title and status of reader have been conferred upon Dr. R. S. Bradley, senior lecturer in the Department of Inorganic and Structural Chemistry; and the title and status of reader in mathematical chemistry have been conferred upon Dr. D. W. J. Cruickshank, lecturer in mathematical chemistry in the same Department.

\section{Announcements}

Mr. H. Wriliamson, formerly assistant to the director of the Division of Applied Biology of the National Research Council of Canada, has been appointed scientific liaison officer for the National Research Council in Washington, D.C. In co-operation with the Department of External Affairs, he will act as scientific attaché at the Embassy. Mr. Williamson replaces Dr. J. D. Babbitt, who was transferred to Ottawa to serve as assistant director (Information Services) in the Division of Administration of the National Research Council.

Mr. P. O. Wolf, lecturer in civil engineering at the Imperial College of Science and Technology, has been appointed to the university readership in hydrology tenable at that College.

Prof. J. B. S. Hampane will deliver the fourth Bateson Lecture at 5 p.m. on July 19 in the Library of the John Innes Horticultural Institution. The subject of his address will be "The Theory of Evolution, before and after Bateson". Inquiries should be made to the Regisurar, John Innes Horticultural Institution, Bayfordbury, Hertford, Herts.

THE Heald Green Laboratories of the British Rayon Research Association at Wythenshawe, Manchester, will be open to visitors on May 9 and 10.

The Fulmer Research Institute is to hold an open day on July 2 to mark the tenth anniversary of the opening of its laboratories at Stoke Poges, Buckinghamshire. On that day the laboratories will be available for inspection, and some aspects of the work of the Institute will be exhibited.

The Cortina-Ulisse European Prize of one million lire (about $£ 570$ ), which is awarded annually by the magazine Ulisse, is being offered this year for a work of popular science on the possible peaceful applications of atomic energy. Only original works printed for the first time in Europe during the past five years will be eligible. Works published in a language other than Italian, French, German, English or Spanish must be accompanied by a translation into one of those languages. Five copies should be sent, before May 31, either by the author or by the publisher, to the Editor of Ulisse, Sezione Premio Europeo Cortina Ulisse, Corso d'Italia 43, Rome.

THE new Division of Inorganic Chemistry of the American Chemical Society is seeking more members among scientists both in and outside the United States who are interested in inorganic chemistry. The membership subscription of 3 dollars a year may be sent to Dr. L. B. Asprey, Los Alamos Scientific Laboratory, Box 1663, Los Alamos, New Mexico. Dr. Asprey will also receive papers for presentation before the Division at the National Meeting of the Society to be held during September 8-13, in New York. Symposia are being organized on "New Industrial Inorganic Chemicals" and "High Temperature Inorganic Chemistry". The Division will also jointly sponsor a symposium with the Division of Physical and Inorganic Chemistry on "The MetalCarbon Bond".

THE Chemical Society has arranged a meeting in Glasgow on "Recent Advances in the Chemistry of Terpenoid Compounds" during July 11-12. Further details can be obtained from the General Secretary, Chemical Society, Burlington House, London, W.1.

THE European Molecular Spectroscopy Group will be holding a meeting this year at the Univorsity of Freiburg im Breisgau, Germany, during July 9-13. A wide range of topics in molecular spectroscopy will be discussed. Information about attendance at the meeting and the presentation of papers can be obtained from Prof. R. Mecke, Institute of Physical Chemistry, University of Freiburg im Breisgau.

The fifth general assembly of the Societa Italiana di Geofisica $\Theta$ Meteorologia is to be held in Genoa during April 23-25. Immediately afterwards, on April 26, the Centre International de Recherches sur la Météorologie de la Méditerranée is to hold a meeting in the Istituto Geofisico, University of Genoa, in order to decide on future research programmes and the necessary financial arrangements. Further details can be obtained from the Secretariat, Istituto Geofisico, vis Balbi 30, Genova.

THE annual Convention of the British Institution of Radio Engineers will be held in Cambridge during June 27-July 1. The third Clerk Maxwell Memorial Lecture will be delivered during the Convention by Sir Lawrence Bragg, director of the Davy-Faraday Laboratory of the Koyal Institution, who will sperk on the diffraction of short electro-magnetic waves. Further information can be obtained from the General Secretary, British Institution of Radio Engineers, 9 Bedford Square, London, W.C.1.

The British Institution of Radio Engineers has arranged a convention on "Electronics in Auto. mation", to be held in the University of Cambridge during June 27-July 1. Thirty papers are to be prosented in six sessions on : office machinery and information processing; machine tool control; chemical and other processes; simulators; auto. mation in the electronics industry; and automatio measurement and inspection. Further information may be obtained from the Institution's offices, 9 Bedford Square, London, W.C.1. 